\title{
遺伝的プログラミングによる \\ 潮位偏差の予測に関する研究 \\ STUDY ON PREDICTION OF SEA LEVEL ANOMALY \\ USING GENETIC PROGRAMMING
}

\author{
西田 渉 $1 \cdot$ 松田 良寛 2 野口 正人 3 \\ Wataru NISHIDA, Yoshitomo MATSUDA and Masato NOGUCHI \\ 1正会員 博士 (工) 長崎大学助教授 工学部社会開発工学科（７ 852-8521 長崎県長崎市文教町1- 14) \\ 2学生会員 長崎大学大学院 生産科学研究科博士前期課程 (同上) \\ 3フェロー 工博 長崎大学教授 工学部社会開発工学科 (同上)
}

\begin{abstract}
Recently, as the progress of information- communication technologies, lots of valuable data related to water environment are automatically observed and some of them are opened to public in real time through media such as internet etc. It is expected that these data will contribute to the solving problems occurred at real water areas.

In this study, regarding the facts that sufficient data are recently available to realize the data- driven modelling, genetic programming was newly developed and its applicability to the prediction of sea level departure was discussed with comparing to the results obtained from artificial neural network model. Although the training of genetic programming was executed for limited data, construction of tree was successfully established by regarded genetic procedures. Obtained tree considerably simulates the temporal changes of sea level anomaly observed at Kuchinotsu port. While, for obtaining the tree which outputs results with smaller errors, computational conditions, such as observed data fed to model and parameters on genetic procedures, have to be chosen with care.
\end{abstract}

Key Words : data-driven model, genetic programming, artificial neural network, sea level anomaly

\section{1.はじめに}

河口や沿岸域の流動状況を予測する手法としては , 所 定の支配方程式を基礎とする数理モデルを数值シミュ レーションする手法が最も一般的であり，現地への適用 をとおして，これまでに多くの成果を上げてきている． ただ , 予測精度の高い結果を得るためには, サブグリッ ドスケールの物理現象のパラメタリゼーションによって 導入された各種のモデル係数を適切に評価しておく必要 がある . これらの係数值については, 遺伝的アルゴリズ ム(GA) やAdapti ve Q uster Covering Nethod などの大 域的最適化手法による推定力試みられてきているが-4 值の算出に相心の計算時間を要することもあり，実際に は限られた一定期間の実浿青報に基ついて現地への適用 性力議論されるに止まっている .

ところで，近年，ICT (I nf or nati on- Conmuni cati on Technol ogy) の進展に伴って, 実水域における各種の物 理現象か実時間的にモニタリングされると共に，実測值
が電子データとして蓄積されてきている .これらの情報 の活用について，モデル解析の範囲で言えば，物理モデ ルの検定，検証に用いられている，弚の一方で，実現象 の予測にあたっては，これら貴重なデータに基ついて， 計算機に害現象の傾向を自己学習させ，実用的なモデル を構築させていくDat a D i i ven Nodel ( DDM による手法も ， 蓄積データ数の増加によって実現可能になってきている と言え光うである。DOMは，比較的長期間の実測値を 使って, 実証的にモデルか甡成されるため, 兴の長期予 測への適用力期待される.もちろん，こうした手法の予 測結果は実測値の精度に依存するため, 計算に際しては 実測誤差か可能な限り除去されておく必要があることは 言うまでもない .

DDNの代表例としてニューラル・ネットワークモデル が上げられるが, 本研究では, 進化論的手法に基づく DDN乎法の一つとして, 水工学分野においても, 弚の利 用か始められている遺伝的プログラミング手法を用いる こととし，これを潮位偏差の予測に適用を試みることに した5,の . 具体的には , 遺伝的プログラミングの評価結 
果をニューラル・ネットワークによる結果と比較しなが ら計算精度の検討を行なつた . また，長期変化の予測に 本手法を適用する際の問題点についても検討した .

\section{DONO概要}

ここで, 本研究で用いた二つのモデルの概要について 記しておく

（1）遺伝的プログラミング

遺伝的プログラミングは , 遺伝的アルゴリズムと同樣 に，進化論的考え方に基づく計算手法の一つであり，生 物の遺伝子の複製, 選択・淘汰といった自然界て観察さ れるメカニズムを基本として構成されている．ただし， 遺伝的プログラミングでは, Nechi ne Learning によっ てプログラムの自動合成を目指している点が遺伝的アル ゴリズムにはない特徵の一つとなっている ${ }^{68}$.

ここで, 本研究で用いられた遺伝的プログラミングの 処理手続きを示すと，図-1のとおりである.今回の計算 では, 各個体は, 入力データに対する関数となるように 表現するものとし，兴の木構造をLi sp言語のS式で表わ すようにしている，処理手続きについては，まず，個体 群として $M$ 個の個体をランダムに生成し, 各個体の表現 木から得られた計算值と実測值から適合度を評価する。 続いて, 個体の適合度の良否に基づて, 個体群に遺伝 オペレータを作用させ , 次世代の個体群を生成させるも のとした.なお，この処理の中て適用されるオペレータ は，GAでも標準的に適用される選択操作と遺伝子操作 (突然変異, 交叉) としている. 帯の内, 突然変異では, 表現木の終端・非終端ノードラベルの変更と, 部分木の 新規生成を行っている.交叉では，個体群から選択され た親となる1対の表現木に対して，ルートノードを除く 部分木の取り替えを実行している.この取替え位置の深 さに関しては，部分木力効果的に積み上げられるよう， 浅い層のノードが選択される確率が高くなる深さ依存型 交叉とした . 本計算では，表現木を固定長として取り扱 うものとしていることから，交叉による部分木の取り替 えは, 同じ階層にあるノード間でなされた . 部分木の削 除は, 終端ノードが全て零て構成される部分木に入れ替 える突然変異によって実現させるものとした .

表現木に導入した終端記号と非終端記号は, 表-1のと おりである .すなわち, 計算対象となる潮位偏差は，S 式て構成される表現木で算出される . また，終端記号と しては, 潮位偏差に影響をもたらすと考えられる気象学 的項目として，現時刻と過去 6 時間の大気圧，時間降雨 量，緯度・経度方向の風速を取り上げることとし，これ らに加えて, 表現木に含まれる係数值として , ランダム に発生させた定数が用いられた。なお, 気象学的項目に ついて , 各項目の最大值て基準化されており，係数值 は-1から1までの実数とされている.非終端記号として

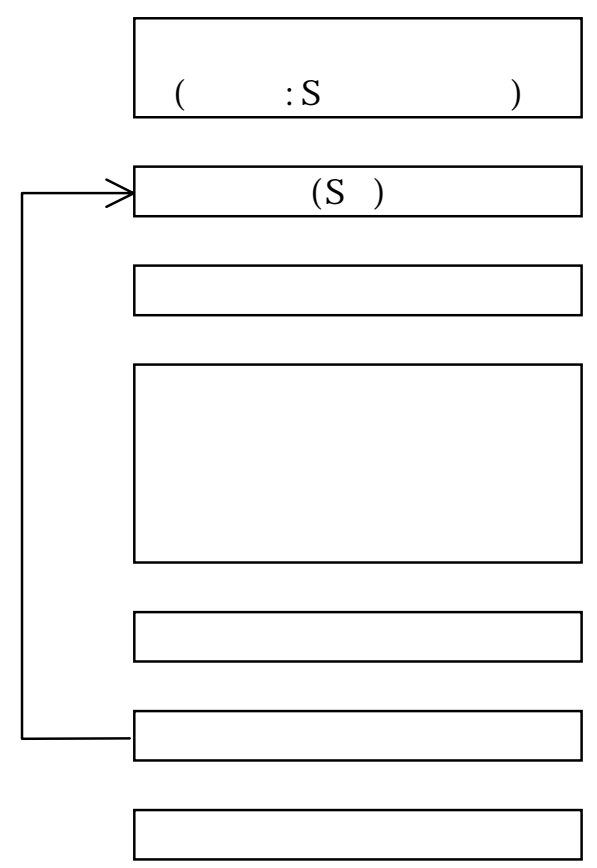

図-1 遺伝的プログラミングの処理手続き

表-1 終端記号と非終端記号

\begin{tabular}{|c|c|}
\hline \multirow[t]{2}{*}{ 終端記号 } & $\begin{array}{l}\text { 気象学的時系列データ } \\
\text { 大気压, 時間降雨量, 風速 } \\
\text { [ 当該時刻と過去 } 6 \text { 時間の1 時間 } \\
\text { 毎の值を最大值で基準化] }\end{array}$ \\
\hline & $\begin{array}{l}\text { 定数値 } \\
\text { [-1〜0, 0〜1の実数を初期に200 } \\
\text { 個づつランダムに生成] }\end{array}$ \\
\hline 非終端記号 & $\begin{array}{c}+{ }^{*} \quad \text { ※Li spのS式で+A B), (* C } \\
\text { D) と記述される.A, B, C, D } \\
\text { は終端記号またはは部分木 }\end{array}$ \\
\hline
\end{tabular}

表- 2 遺伝的プログラミングの設定条件

\begin{tabular}{|c|c|}
\hline 設定項目 & 値 \\
\hline 表現木の最大層数 & 7 \\
\hline 1世代の個体数 $(M)$ & 1000 \\
\hline エリート選出確率 $\left(P_{e r}\right)$ & 0.15 \\
\hline 交叉確率 $\left(P_{c r}\right)$ & 0.7 \\
\hline 突然变異確率 $\left(P_{m t}\right)$ & 0.7 \\
\hline
\end{tabular}

は, 当初, 四則演算子並びに累乗・指数関数としていた が, 予備計算の結果から, 解の収束が進み難かつたこと, また係数值に負の值を含めたことから，\{+*\}を用いた . これらは, いずれも二つの引数を持つ関数記号である .

各表現木の適合度については，算出値と実測值を用い て , 以下のように評価することにした .

$$
E R=\frac{1}{N} \sum_{n=1}^{N} w_{o b s, n}\left|O B S_{n}-C A L_{n}\right|^{2}
$$

ここに $, N:$ 実測データの総数,$w_{o b s, n}$ : 実測データの番

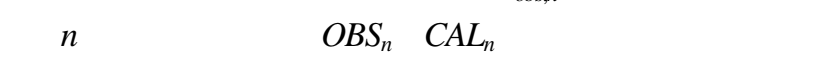


と算出値 ,である.$w_{o b s, n}$ の值については, 基本的に1 としたが, 台風の影響と見られる潮位偏差の増加があっ たものは，幾つかの試行計算の結果を参考に12とした . また ，モデルに入力する時系列データを入手できなかっ た期間については上記の重みを零とすることで適合度の 評価対象から外している.

ここで, 以降の計算で用いた遺伝的プログラミングの 設定条件を表-2にまとめておく . 一個体の表現木の最大 層数は 7 層とした . 兴の結果, 最下層には128個の終端 ノードか配されている.個体群は，1000個の個体で形成 されており，個体の選択は，適合度の計算結果に基づく エリート戦略とルーレットルールを併用したものによっ ている. 選出された個体の交叉確率は0.7とされた . 突 然変異確率については, 条件の異なる幾つかの予備計算 の結果から，この確率值を低く設定すると，世代交代が 進むにつれて最大適合度は順調に高くなるものの，ある 適合度以上には適合度の改善が見られなかった .これは， 表現木の形式が早期に収斂し，局所解に陥つたためと推 察される . そのため, 今回の計算では, 突然変異確率を 0.7とすることて個体群の多樣性を高め, 局所解からの 脱出を図ることとした . 個体の適合度は, 部分木の非終 端記号の構成とともに，終端記号の定数値の与え方に よっても值が向上することも予想されることから，ある 回数の世代交代がなされた時に定数ノードの設定值の改 善を図るために, 各定数にランダムサーチを施すことに した . 計算の環境については，OSをN\$W Wdousとして Vi sual Basi cて計算の全体的な流れを制御し，表現木を 記述しているLi spスクリプトの計算は，UN Xエミュレー タの下でguile-16.5を使って行なっている.

（2）ニューラル・ネットワークモデル

ニューラル・ネットワークモデルは, 遺伝的プログラ ミングの計算結果の比較に用いられた .

このモデルの構成は, 図-2のとおりであり, 構成か比 較的簡単なフィードフォワード型の多層モデルとされた .

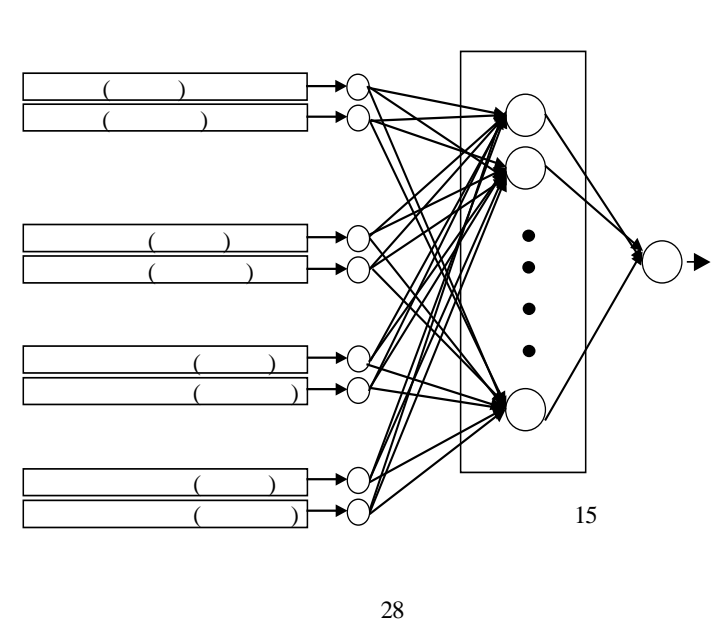

图 2 ニューラル・ネットワークの構成
すなわち, 中間層を 1 層とした全 3 層型とし , 中間層に 15個 , 出力層に1個のノードを配置した . モデルの学習 は, 計算値と実測值との差に基づいて , バックプロパ ゲーションによって行なうことにした . 1セットの学習 用データに対する計算回数は 5 万回としている. 入力層 に与える実測值については, 遺伝的プログラミングで与 えたものと同一種の28個のデータとしているが, 実測值 の最大值と最小值を用いて零から 1 の範囲に変換されて いる．モデル中に配されたデー各処理ノードでは，一般 に用いられるシグモイド関数 : $f(x)=1 /\{1+\exp (-a x)\}$ を用 いて出力值を算出することにした .なお，この式にある 係数aについては, 実際に観察された学習の進行状況か ら0.05としている。

\section{3 .計算結果の比較}

（1）計算対象地点と入力データ

前章て説明したモデルによる潮位偏差の計算は , 図-3 に示される島原湾湾口部に位置する口之津港を対象に行 なわれた .この港湾か取り上げられたのは, 気象庁から 1時間毎の潮位偏差のデータか配信されており，十分な

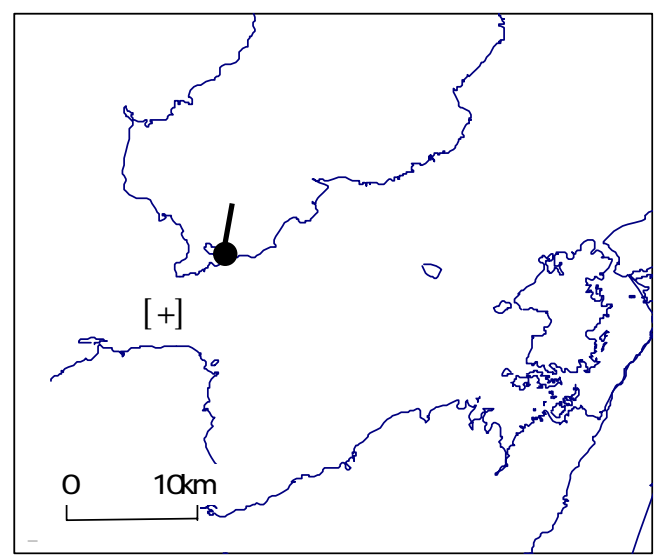

図3 口之津港の位置図

(図中の [+] は,入力データとしたMSMのグリットポイント指す)

実測結果を入手可能であつたこと，また，これまで著者 らは島原湾の潮流の数值シミュレーションを実施してき ており" , 海上の気象学的条件の変化を考慮したシミュ レーションに本計算結果を反映させる目的もあつたこと によっている .

計算の対象期間は2004年 9 月であり，先述のように， 口之津港における同期間の潮位偏差の実測值は，気象庁 の報告值としだ . 大気圧や時間降雨量等の気象学的時 系列データについて , 海上での気象諸量の変化が潮位 偏差を生じさせる主たる要因と考えられることから，以 下の計算では, 現在, 気象庁で運用されている気象擾乱 の短期予測モデルの一つであるNesoscal eモデルによつ て数値予報された值を利用することにした .この予測モ 


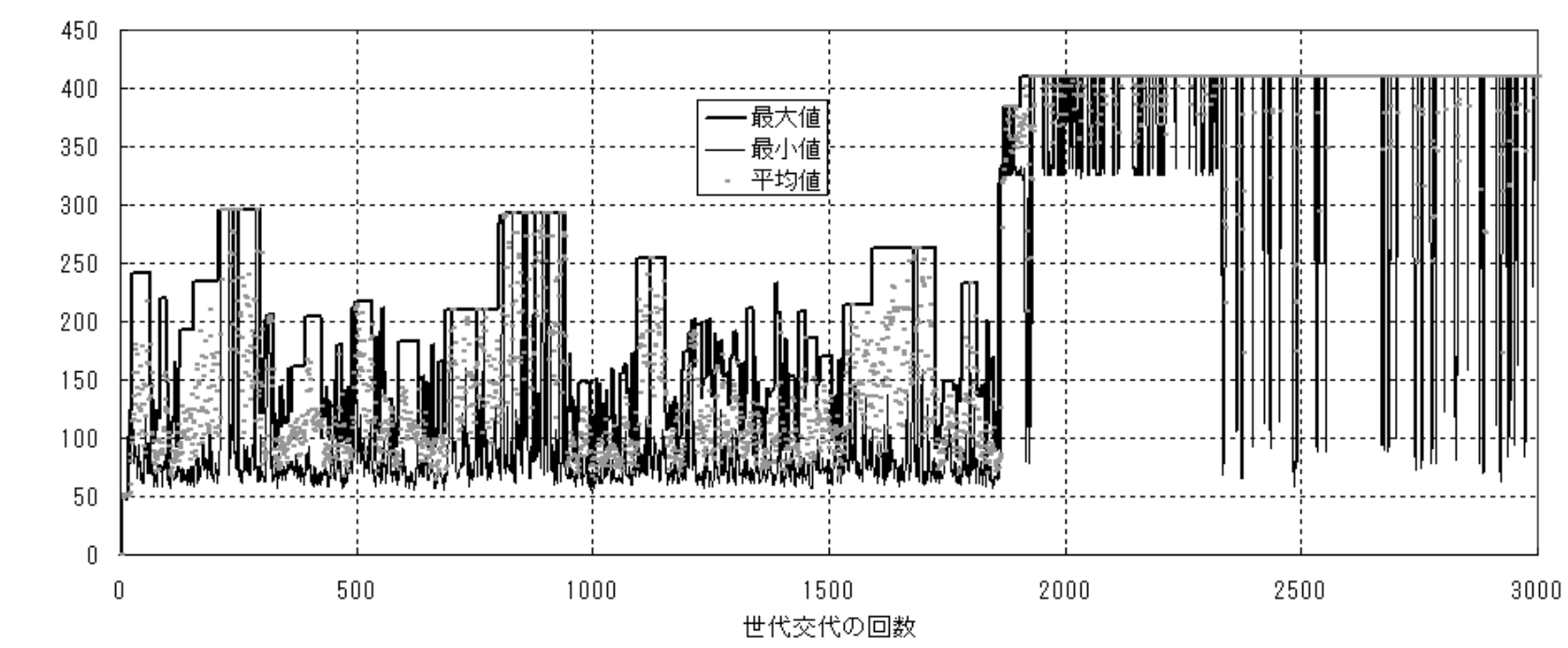

図-4 遺伝的プログラミングの表現木の適合度の変化

デルの解像度は, 緯度 , 経度方向に0.1×0.1250であ り，距離にして約10kmとなっている10．なお，二つの DDNの学習に用いたデータの総数は，数值予報值を取得 できなかった期間を除くと610個となっている .

\section{(2) モデルの計算結果}

ここで，まず，遺伝的プログラミングによって算出さ れた適合度について，世代交代に伴う変化の樣子を図-4 に示す . 同図には ,一つの個体群の内で, 適合度の評価 結果の良い上位10位までの算出結果の平均値と，最大值 並びに最小值が逆数として表示されている.また，図に 描かれた世代交代の回数は3000回までの結果である.

この図を見ると, 計算開始後, 直ちに最大值と最小值 は増加するが，1863回目の世代交代がなされるでの間 において，とくに最大值は，凹凸状の分布を示しながら 大きく変化していることが分かる. 兴の一方で, 最小值 は最大值と同程度の值に近づく樣子も見られるが , 概ね 60から100の範囲にある .こうした結果が得られたのは， 最大值の分布にあっては, 個体群からの個体の選出処理 の中に取り入れられたエリート戦略によって，世代交代 の際に適合度の高い個体力優先的に選出され，次世代に 引き継がれるものの，全く同一の表現木を持つ個体で上 位が占められておらず，これらの表現木の構成がルー レット選択や部分木の交叉によって変化しやすかったた めと考えられる.このことは, 平均值が最大值に近い部 分に偏っていないことからも推察される.併せて, 突然 変異確率を比較的高い值に設定していることによって， 世代交代の履歴に余り影響されていない適応度の高い個 体か澵規に生成されていることも最大值がこのような分 布になった原因の一つと考えられる．

図に示された計算結果の後半部について , 最大値に 微小な適合度の向上があるものの，1/ERの值は，410程 度で分布している.これは, 2600回目付近では最小值も 最大值に等しくなるなど，最小値と最大值の差が前半部

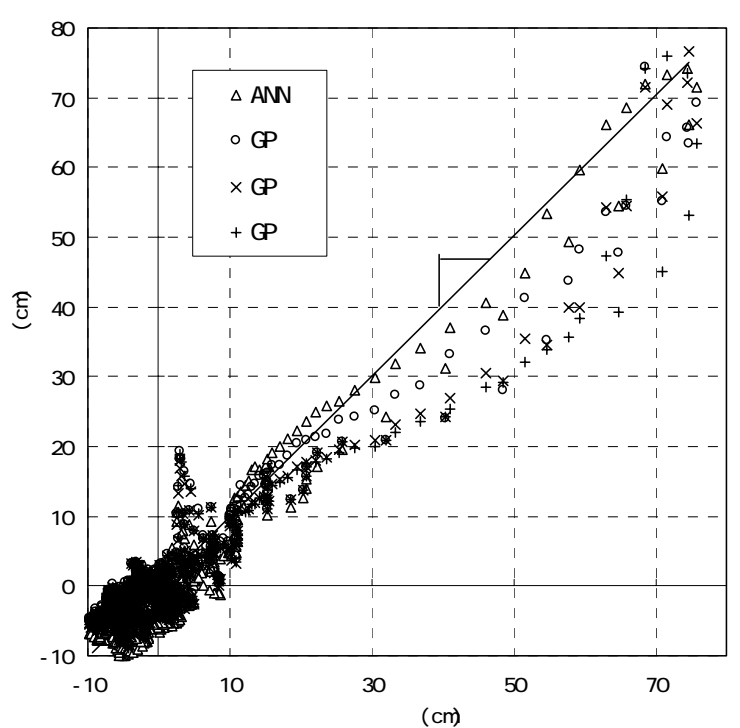

図 5 二種類のモデルの計算結果と実測結果との比較 (GP 遺伝的プログラジグ,ANN :ニューラル ネッットークモデル)

表-3 ERとTCの評価結果

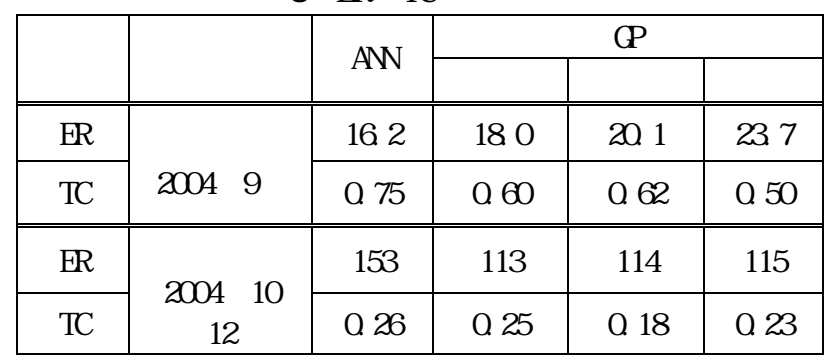

に比べて小くなっており，上位の表現木の構成にばら つきが少なくなった結果, 計算の手続きに含められた遺 伝才ペレータ処理に対して, 堅牢な個体群へと遷移した ことによるものと思われる、なお，ここでは, 生成され た表現木の変化状況を具体的に示していないが, 図-4の 最大值か急増した時の構成の変化を調へててると，1913 回目に1/ERが383から409に変化した時や, 適応度に微小 


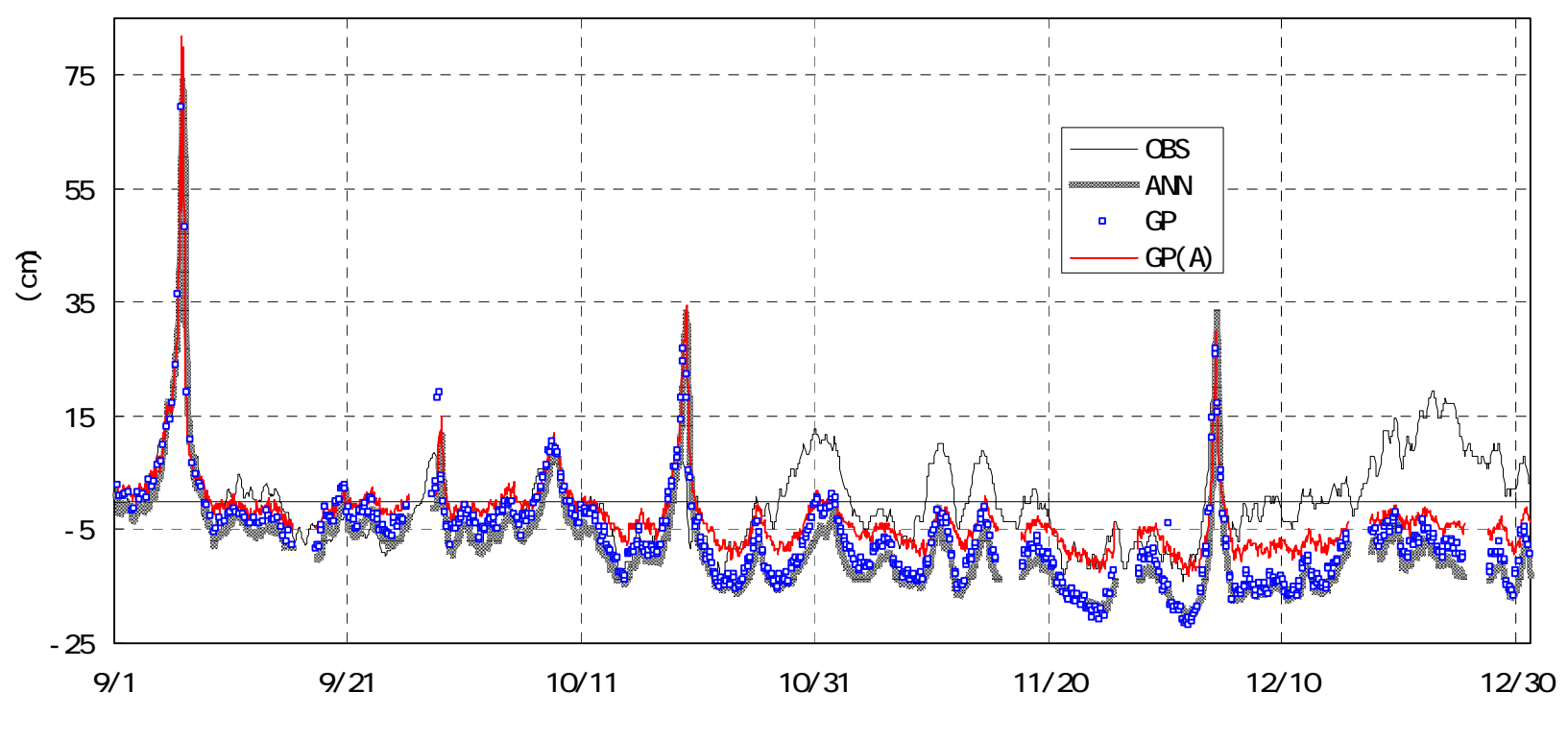

図-6 潮位偏差の実測値と計算結果

な改善があつた場合などに , 一つ前の個体群で上位の個 体群を母体とする部分木の変化か影響を与えているよう であったが, 弚れ以外では, 部分木の構成の変化状況か ら，下位の個体同士の交叉や突然変異によって適合度が 改善されているようである.

つぎに , 遺伝的プログラミングとニューラル・ネット ワークモデルの計算結果の比較として, 実測結果への対 応状況を示すと, 図-5のとおりである.この図には, 遺 伝的プログラミングによって得られた表現木の内 , 図-4 に記入された(1)，(2)，(3)の各世代の最良個体による算出 結果力描かれている。

図-5から，いずれのモデルも実測結果を表現する傾向 にあり，実測值が20cn程度以下では, ばらつきがあるも のの , 同程度の算出精度となっている . ただ , 表- 3に表 記されているように，9月の学習データに対するER值は， ニューラル・ネットワークモデルにおいて最も小さく， 実測值の全体的な再現性が他に比べて高い . 遺伝的プロ グラミングについては, 式( 1)の重みを変化させたこと もあり，潮位偏差の最大值付近において実測值との差が 縮まっているが, 偏差が30〜70 cmとなる範囲で值が低め に算出されている .この程度はERの值か滈くなるにつれ て大きくなる傾向にある .

ここで, 計算結果の再現性を評価する別の指標として， 以下の式( 2) として定義される值( TC) を求めると，表- 3 の下欄のとおりである .

$$
T C=\frac{\sum_{n=1}^{N} \delta O B S_{n} \cdot \delta C A L_{n}}{\sqrt{\sum_{n=1}^{N} \delta O B S_{n}^{2}} \sqrt{\sum_{n=1}^{N} \delta C A L_{n}^{2}}}
$$

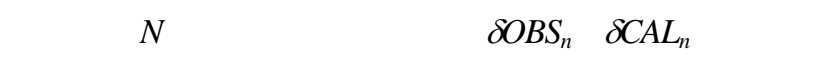
れ実測データと算出値の時間変化量, である.
式( 2)よる算出結果を見ると，ERの結果が良好であつ たこともあり，ニューラル・ネットワークモデルにおい てTCの值が他者に比べて高い . 一方で, 遺伝的プログラ ミングでは，ERの結果が表現木(1)，(2)の順に良かったが， TCの良否については, 光れらの順序が屰転しており，表 現木(2)の計算結果か実測值の時間変化の傾向をより良く 再現していることを示している.今回の計算処理では， 個体の適合性の評価にTCの值を反映させていないが こ こ の評価結果を併用する必要性を示唆しているものと思わ れる.ただし，これら二つの指標は，表現している誤差 の内容が異なることもあり, 取り上げられる問題によっ て議論されるべきものと考えられる . ERのような全体的 な誤差の結果にTCの結果を具体的にどの程度寄与させる かは , 今後検討していきたい .

以上に記した学習後のモデルの検証として ，2004年10 月から12月までの潮位偏差の評価に適用した結果を表- 3 に記している、なお，この期間の計算に用いたデータは 学習計算の光れと同種であり, 弚の数は1977個である. また , 一連の計算から得られた2004年 9 月から12月まで の結果は, 図一に示されるとおりである .

表に記載された結果から, 各モデルのERとTCのいずれ も精度が低下しており，ニューラル・ネットワークモデ ルのTは遺伝的プログラミングの表現木(1)と同程度の值 になっている．予測結果の樣子を図６に見ると，10月中 旬までの変化や12月初旬に台風力接近したことによる潮 位偏差の上昇などは表現されているが, 10月末からの平 時の変化は低く評価されている.こうした結果になった 理由として, 計算条件に関しては, 過学習などモデルの 学習の程度や, 季節風の変化といった未学習データの混 入等か挙げられる。

乥こで, 学習用の入力データに11月の值を追加して遺 伝的プログラミングの再学習を試みた . 学習データの数 
は1236個である .この条件で得られた結果は, 図-6に GP(A) として併記されているとおりであり，ERとTCの値 は学習期間で68.7, 0.69 ，また検証期間で103，0.28で あった . 図-6から，11月の再現性は期待した以上には改 善されてはいないものの, 10月の計算精度を概ね保持し つつ, 全体的な算出結果か改善されていることが分かる. モデルの構造から容易に予想されることではあるが , 本 研究で主に取り上げた遺伝的プログラミングの計算精度 は, ニューラル・ネットワークモデルと同樣に ,やはり 学習用データの数や質などに強く依存するものと言える． とくに，10月や12月末期の計算結果の向上にあたっては， モデルの計算条件の検討と共に入力データの適切な選定 が必要になるものと考えられる.

\section{4.おわりに}

本研究では, 近年, 多くの機関の努力によって水工学 的に有用な実測值力蓄積されつつあること，また，これ ら豊富な情報を活用したモデル解析か河能となっている ことを考えて，DONの一つである遺伝的プログラミング を用いた潮位偏差の予測を試みた 。

产の結果 , 今回の計算条件では適合度の評価值力腹杂隹 に変化しており，世代交代の停止条件の設定か溶易では ないものの，計算条件が適切になされれば，二ューラ ル・ネットワークモデルと同程度の予測精度を備えた表 現木か得られることが示されたものと考えている. 兴の 一方で, 計算精度の向上には, 学習用のデータや計算条 件の設定など，DDM=特有の問題を解決せねばならない ことも併せて示された .なお，ここで利用した二つのモ

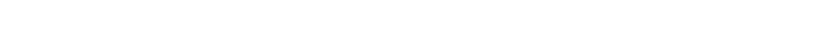
があることは言うまでもない.とくに遺伝的プログラミ ングについては，予測計算の手続き(プログラム) を自動 生成できるという点がニューラル・ネットワークにはな い特徵である. 今回の計算で, 関数式の導出を目的と して演算子のみか非終端記号に適用されたが，これに加 えて , 条件分岐などを表す特別式を導入することも可能 である.こうしたプログラムの生成条件に自由度を増し た場合の適用性に関しても検討したい．

今後，これまでに記した課題に取組むと共に，ケース スタディを増やすことで, 遺伝的プログラミングの実問 題への適用性について引き続き検討していきたいと考え ている。
謝辞：本研究を遂行するにあたり，UNESOOIトの D mitri P. Sol onati ne 助教授からDDWか活用に関して 有益なアドバイスを戴いた .ここに記して深甚なる謝意 を表します．また，入力データの前処理並びに計算の実 施にあたっては, 岡崎久典氏を初めとする本学河川工学 研究室の諸氏に協力を戴いた .ここに謝意を表します．

\section{参考文献}

1) Solomatine, D.P. and Dibike, Y. B. : Automatic calibration of groundwater models using global optimization techniques, $J$. Hydrological Sciences, 44 (6), pp.879-894, 1999.

2) Maskey, S., Jonoski, A., and Solomatine, D. P. : Groundwater remediation strategy using global optimization algorithms, $J$. of Water Resources Planning and Management, Vol. 128, No.6, pp. 431-440, 2002.

3) Noguchi, M., Solomatine, D. P. and Nishida, W.: Calibratin of water quality model by global optimizatin techniques, Proc. 5th Int'l conf. on Hydroinformatics Vol. 1, pp. 464-469, 2002.

4) 西田渉, 野口正人, D.P.Solomatine : 気象予報情報の潮流予 測への適用に関する研究, 水工学論文集, 第49巻, pp. 1279 $1284,2005$.

5) Giustolisi, O. and Laucelli, D.: Modeling rainfall-funoff by genetic programming: resut from two experimental urban basins, Proc. 5th Int'l conf. on Hydroinformatics Vol. 2, pp. 1484-1491, 2002.

6) Babovic, V., Harrington, J. R. and Keijzer, M.: Generation of settling velocity equations for sand grains using genetic programming, Proc. 6th Int'l conf. on Hydroinformatics Vol. 2, pp. 1631-1638, 2004.

7) 伊庭斉志: 進化論的計算の方法, 東京大学出版会, 1999.

8) 伊庭斉志: 遺伝的プログラミング, 東京電気大学出版会, 2001.

9) 気象庁：ホームページ 海洋の情報資料, UR http: //www. dat a. ki shou. go.j p, 2004.

10) 気象庁予報部：メソ数値予報の実用化に向けて, 数値予報 課報告, 別冊第44号, p. 79, 1998.

(2005. 9. 30受付) 